\title{
SKRINING BAKTERI PENDEGRADASI INULIN DARI RIZOSFER UMBI DAHLIA MENGGUNAKAN INULIN UMBI DAHLIA
}

\author{
Minda Azhar ${ }^{* 1}$, Yuni Ahda ${ }^{2}$, Ihsanawati ${ }^{3}$, Fernita Puspasari ${ }^{3}$, Suci Mawarni ${ }^{1}$, \\ Boni Risa ${ }^{1}$, Dessy Natalia ${ }^{3}$ \\ ${ }^{1}$ Laboratorium Biokimia, Jurusan Kimia, Fakultas Matematika dan Ilmu Pengetahuan \\ Alam, Universitas Negeri Padang, Jl. Prof. Dr. Hamka, Air Tawar, Padang \\ ${ }^{2}$ Laboratorium Biologi, Jurusan Biologi, Fakultas Matematika dan Ilmu Pengetahuan Alam, \\ Universitas Negeri Padang, Jl. Prof. Dr. Hamka, Air Tawar, Padang \\ ${ }^{3}$ Kelompok Riset Biokimia, Fakultas Matematika dan Ilmu Pengetahuan Alam, Institut \\ Teknologi Bandung, Jl. Ganesha 10, Bandung \\ email:minda@fmipa.unp.ac.id, ahdayuni@yahoo.com, ihsanawati@chem.itb.ac.id, \\ fernita_puspasari@yahoo.com, sucimawarni@gmail.com,risa_boni@yahoo.com, \\ dessy@chem.itb.ac.id
}

\begin{abstract}
Inulin degrading bacteria is a potential source of inulin degrading enzymes, an enzyme which convert inulin into fructose and fructooligo-saccharides (FOS) prebiotic. The purpose of the study was to find inulin degrading bacteria. The methods that used to find inulin degrading bacteria were indirect and direct isolation method using inulin as the sole carbon source. Bacteria was characterized colony morphology. Inulin degrading bacteria were screened from two rizosphere dahlia tuber in West Sumatera (Solok and Padang Panjang). In the research has been found five inulin degrading bacteria isolates. Isolate bacteria RZ-01, RZ-02 from rizosphere dahlia tuber in Padang Panjang, isolate bacteria $\mathrm{A} 1-\mathrm{KG}, \mathrm{A} 2-\mathrm{KG}$ and $\mathrm{UKG}$ from rizosphere dahlia tuber in Solok. All isolates grow at room temperature and $40^{\circ} \mathrm{C}$. All isolates were classified as mesophilic bacteria. Shape and colour of RZ-01, A2-KG and UKG colonies were circular and white respectively. RZ-02, A1-KG colonies were circular and yellowish.
\end{abstract}

Keywords : mesophilic bacteria, inulin-degrading bacteria, inulinase, inulin, fructose

\section{PENDAHULUAN}

Prebiotik FOS dan fruktosa merupakan senyawa yang sangat penting pada industri makanan, minuman dan farmasi (Sirisansaneeyakul et al., 2007; Singh, 2006). Senyawa ini dapat diperoleh dari hidrolisis inulin menggunakan katalis enzim penghidrolisis inulin. Fruktosa dapat juga diperoleh dari pati. Pembuatan fruktosa dari inulin lebih efisien dan ekonomis dibandingkan dari pati (Zittan, 1981). Oleh sebab itu, enzim yang terlibat pada reaksi hidrolisis inulin yaitu inulinase atau levanase adalah pilihan yang paling tepat untuk memproduksi fruktosa dan prebiotik FOS dari inulin.

Inulinase dan levanase dari bakteri adalah pilihan yang lebih baik untuk mengisolasi enzim tersebut dalam jumlah yang banyak. Inulinase dan levanase umumnya aktif pada

substrat inulin, levan dan sukrosa. Inulinase dari Bacillus polymyxa 
E-ISSN : 2549-7464, P-ISSN : 1411-3724

dapat menghidrolisis sukrosa, levan, raffinosa and inulin (Kwon et al., 2003). Exoinulinase dari Aspergillus awamori dapat menghidrolisis ikatan $\beta 2,1$ - sebaik $\beta 2,6$ pada fructooligosaccharides (inulin dan levan dengan DP 4-7) (Kulminskaya et al., 2003). Levanase dari Bacillus subtilis yang diekspresikan dalam Escherichia coli aktif pada levan, inulin and sukrosa (Wanker et al., 1995), sedangkan exolevanase dari Gluconacetobacter diazotrophicus SRT4 dapat menghidrolisis levan, inulin, dan sukrosa (Menendez et al., 2002).

Tipe aksi levanase dan inulinase pada substrat inulin adalah endo- atau exo-. Tipe aksi enzim ini pada substrat inulin dan levan menghasilkan produk yang berbeda. Fruktosa dapat diperoleh dari inulin meng-gunakan exoinulinase atau exolevanase, sedangkan FOS dapat diperoleh dari reaksi hidrolisis inulin menggunakan endo-inulinase atau endolevanase. Kombinasi kedua tipe aksi enzim ini mempunyai efek sinergik untuk menghasilkan fruktosa dari inulin (Sirisansaneeyakul et al., 2007).

Bakteri pada rizosfer umbi dahlia adalah sumber potensial inulinase. Isolasi dan karakterisasi bakteri yang mempunyai aktivitas inulinase dari sampel tanah telah dilaporkan pertamakali oleh Allais et al., pada tahun 1986. Kebanyakan bakteri yang ditemukan adalah Flavobacterium multivorum (Allais et al., 1986). Bakteri penghidrolisis inulin telah disolasi dari beberapa tempat ekstrim seperti sumber air panas, lokasi dengan $\mathrm{pH}$ tinggi dan lokasi di dasar laut dalam. Actinomycete Nicardiopsis sp.DN-K15 diisolasi dari sedimen laut Jiaozhou Bay China mengekspresikan inulinase alkalitoleran yang mempunyai aktivitas optimum pada suhu $60^{\circ} \mathrm{C}, \mathrm{pH} 8$, mempunyai range aktivitas yang baik dari $\mathrm{pH}$ 5-11 (Lu et al., 2014).

Bakteri penghidrolisis inulin yang berasal dari sumber air panas Bukik Kili di Solok Sumatera Barat telah diidentifikasi sebagai Bacillus licheniformis (Azhar et al., 2013). Fragmen gen pengkode levanase bakteri Bacillus licheniformis telah diisolasi dengan teknik PCR menggunakan primer DPE.slF dan DPE.eR (Azhar et al, 2015). Paenbacillus sp LX16 yang diisolasi dari akar Jerussalem artichoke dapat mendegradasi inulin menghasilkan FOS (Yao et al., 2016). Beberapa bakteri potensial pendegradasi inulin untuk pembuatan fruktosa telah dieksplorasi dari beberapa sumber air panas di Solok Sumatera Barat (Azhar $\mathrm{dkk}, 2015)$. Bakteri penghidrolisis inulin telah diskrining dan telah diidentifikasi dari rizosfer umbi dahlia dan dilaporkan pada artikel ini. Skrining bakteri pendegradasi inulin dilakukan menggunakan inulin dari umbi dahlia.

\section{METODA PENELITIAN}

\section{Bahan}

Bahan yang digunakan meliputi bakteri, reagen kimia, inulin dari umbi dahlia. Bakteri pendegradasi inulin dieksplorasi dari sumber air panas menggunakan media dengan komposisi sebagai berikut $(\mathrm{g} / \mathrm{L}) ; 2 \mathrm{~g}\left(\mathrm{NH}_{4}\right)_{2} \mathrm{SO}_{4}$,

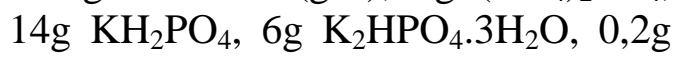
$\mathrm{MgSO}_{4} .7 \mathrm{H}_{2} \mathrm{O}$, $1 \mathrm{~g}$ trisodium sitrat, inulin atau inulin-RBB, dan agar, Castro et al., 1995)). Zat yang digunakan untuk ekstraksi inulin adalah etanol, aguades.

Ekstraksi inulin dahlia dan Karakterisasi

Ekstraksi inulin dari umbi dahlia dilakukan sesuai prosedur Andyani (2001) yang sedikit dimodifikasi. Karaktrisasi inulin mengguna-kan FTIR. Sebagai standar dipakai inulin chicory 


\section{Skrining bakteri pendegradasi inulin}

Bakteri pendegradasi inulin berasal dari sumber air panas di Solok. Bakteri pendegradasi inulin diskrining dengan indirect isolation method menggunakan media yang mengandung inulin sebagai satu-satunya sumber karbon $(\mathrm{g} / \mathrm{L}) ; 2 \mathrm{~g}$ $\left(\mathrm{NH}_{4}\right)_{2} \mathrm{SO}_{4}, \quad 14 \mathrm{~g} \quad \mathrm{KH}_{2} \mathrm{PO}_{4}, \quad 6 \mathrm{~g}$ $\mathrm{K}_{2} \mathrm{HPO}_{4} \cdot 3 \mathrm{H}_{2} \mathrm{O}, \quad 0,2 \mathrm{~g} \quad \mathrm{MgSO}_{4} \cdot 7 \mathrm{H}_{2} \mathrm{O}, \quad 1 \mathrm{~g}$ trisodium sitrat, inulin dan agar (Castro $e t$ al., 1995).

\section{Identifikasi bakteri pendegradasi inulin}

Identifikasi bakteri pendegradasi inulin dilakukan terhadap morfologi koloni dan uji termotoleran. Uji termotoleran dilakukan pada suhu ruang, $40^{\circ} \mathrm{C}$.

\section{Penyimpanan bakteri pada gliserol}

Pembuatan kultur mengandung gliserol sesuai prosedur Sambrook et al 2001. Kultur bakteri $1,5 \mathrm{~mL}$ ditambahkan 0,5 $\mathrm{mL} 60 \%$ gliserol steril, divorteks dan disimpan pada suhu $-20^{\circ} \mathrm{C}$ atau $-70^{\circ} \mathrm{C}$.

\section{HASIL DAN PEMBAHASAN}

\section{Ekstraksi inulin dan identifikasi}

Inulin yang digunakan pada penelitian ini diekstraksi dari umbi tanaman dahlia. Inulin digunakan sebagai sumber karbon satu-satunya pada media seleksi dan media pertumbuhan bakteri pendegradasi inulin. Karakterisasi inulin yang diekstraksi dari umbi dahlia menggunakan FTIR. Sebagai standar digunakan inulin dari chicory. Spektrum FTIR inulin chicory dan inulin dahlia dimuat pada Gambar 1. Pada kedua spektrum tersebut dapat dinyatakan bahwa terdapat gugus $\mathrm{OH}$ pada struktur inulin yang berhubungan dengan pita penyerapan $3267,88 \mathrm{~cm}^{-1}$ pada inulin chicory dan $3270,38 \mathrm{~cm}^{-1}$ pada inulin dahlia.

Pita penyerapan yang berkaitan dengan gugus -OH pada spektrum FTIR inulin yang diekstrak dari Pombalia calceolaria $\mathrm{L}$ adalah pada $3354,85 \mathrm{~cm}^{-1}$
(Pontes et al., 2016). Pada struktur inulin juga terdapat gugus ketal (C-OC-O-C) yang ditunjukkan pita penyerapan $1031,50 \mathrm{~cm}^{-1}$ pada inulin chicory dan $1027,76 \mathrm{~cm}^{-1}$ pada inulin dahlia. Hadirnya fruktosa dengan ikatan glikosida konfigurasi-ß ditunjukkan oleh pita penyerapan pada $825,76 \mathrm{~cm}^{-1}, 933,24 \mathrm{~cm}^{-1}$ pada inulin chicory dan $820,49 \mathrm{~cm}^{-1}$, $931,40 \mathrm{~cm}^{-1}$. Dengan demikian, pola spektrum FTIR inulin chicory persis sama dengan pola spektrum FTIR inulin dahlia.

\section{Skrining bakteri pendegrasi inulin}

Skrining bakteri pendegradasi inulin dilakukan pada media minimal yang mengandung inulin sebagai satusatunya sumber karbon untuk pertumbuhan bakteri. Dengan kata lain hanya bakteri yang mengekspresikan enzim pendegradai inulin yang dapat hidup pada media ini. Bakteri pendegradasi inulin diskrining dari rizosfer umbi dahlia di Solok dan di Padang Panjang (Gambar 1).

Eksplorasi bakteri pendegradasi inulin dilakukan dengan metoda direct isolation dan undirect isolation. Media seleksi yang digunakan adalah media cair yang mengandung inulin sebagai satu-satunya sumber karbon (Castro et al., 1995). Suhu inkubasi seleksi awal adalah suhu ruang (23$32^{\circ} \mathrm{C}$ untuk skrining bakteri dari rizosfer umbi dahlia (Tabel 1). Pada metoda direct isolation, sampel rizosfer umbi dahlia langsung ditumbuhkan pada media padat yang mengandung inulin sebagai satusatunya sumber karbon, kemudian diinkubasi pada suhu seleksi awal selama 18-48 jam. Dengan cara ini tidak berhasil ditemukan bakteri pendegradasi inulin.

Pada metoda undirect isolation, kultur bakteri ditumbuhkan pada 
E-ISSN : 2549-7464, P-ISSN : 1411-3724

media cair yang mengandung inulin sebagai satu-satunya sumber karbon selama 2 sampai 3 hari pada suhu awal seleksi dengan 2-3 kali pemindahkan ke media seleksi cair yang baru, kemudian kultur ditumbuhkan pada media padat yang mengandung inulin sebagai satusatunya sumber karbon selama 18-48 jam. Bakteri pendegradasi inulin pada media seleksi cair ditebar $100 \mu \mathrm{L}$ dengan sprider kaca steril pada permukaan media seleksi padat dengan sederetan seri pengenceran. Selanjutnya dibuat koloni tunggal untuk memperoleh isolat bakteri pendegradasi inulin yang murni (Gambar 2). Kultur isolat bakteri disimpan pada stok gliserol pada suhu $-20^{\circ} \mathrm{C}$.

Tabel 1. Suhu inkubasi seleksi awal sampel pada media seleksi inulin

\begin{tabular}{cccc}
\hline $\begin{array}{c}\text { Sumber } \\
\text { bakteri }\end{array}$ & Sampel & $\begin{array}{c}\text { Suhu } \\
\text { inkubasi } \\
\left({ }^{\mathbf{0}} \mathbf{C}\right)\end{array}$ & Pengamatan \\
\hline $\begin{array}{c}\text { Rizosfer } \\
\text { Umbi } \\
\text { dahlia }\end{array}$ & Umbi & Ruang & Keruh \\
$\begin{array}{c}\text { Padang } \\
\text { Panjang }\end{array}$ & & & \\
\hline $\begin{array}{c}\text { Rizosfer } \\
\text { umbi }\end{array}$ & Umbi & ruang & ruang \\
dahlia & Akar & & Keruh \\
Solok & & & Keruh \\
\hline
\end{tabular}

Dengan metoda undirect isolation telah berhasil ditemukan 5 isolat bakteri pendegradasi inulin yaitu 2 isolat dari rizosfer umbi dahlia Padang Panjang dengan kode isolat RZ-01, RZ-02 dan 3 isolat dari rizosfer umbi dahlia di Solok dengan kode isolat A1-KG, A2-KG dan UKG. Ke lima isolat tumbuh baik pada suhu ruang dan suhu $40^{\circ} \mathrm{C}$. Dengan demikian, isolat RZ-01, RZ-02, A1-KG,

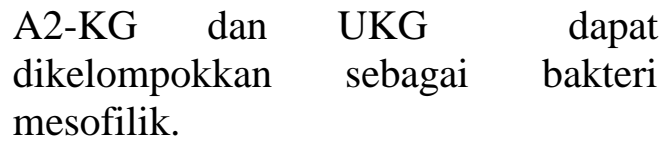

Allais et al. (1987) telah berhasil mengisolasi bakteri pendegradasi inulin (aktivitas inulinase) dengan cara undirect isolation dari bakteri tanah. Metoda undirect isolation juga telah berhasil digunakan untuk mengisolasi bakteri selulase dari sumber air panas Egyptian (Ibrahim dan El-diwany, 2007). Azhar et al., (2013) dan Azhar et al., (2015) telah berhasil mengisolasi bakteri pendegradasi inulin dari sumber air panas menggunakan metoda undirect isolation. Keberhasilan metoda undirect isolation pada isolasi bakteri pendegradasi inulin menandakan bahwa enzim pendegradasi inulin akan diekspresi jika ada inulin. Inulin berperan sebagai inducer dan sumber karbon pada mikroorganisme penghasil inulinase (Sing et al., 2016). Dengan demikian, gen pengkode enzim pendegradasi inulinase termasuk kelompok gen tipe inducible.

Bakteri pendegradasi inulin dapat tumbuh pada media yang mengandung inulin sebagai satusatunya sumber karbon karena bakteri pendegradasi inulin mengekspresikan enzim pendegradasi inulin ekstraselular. Enzim ekstraselular terutama merupakan enzim yang mengkatalisis reaksi hidrolisis molekul besar seperti inulin, selulosa, pati, lipid, kasein, gelatin, kitin. 


\section{Eksakta Vol. 18 No. 2 Oktober $\mid \mathbf{2 0 1 7}$}

E-ISSN : 2549-7464, P-ISSN : 1411-3724

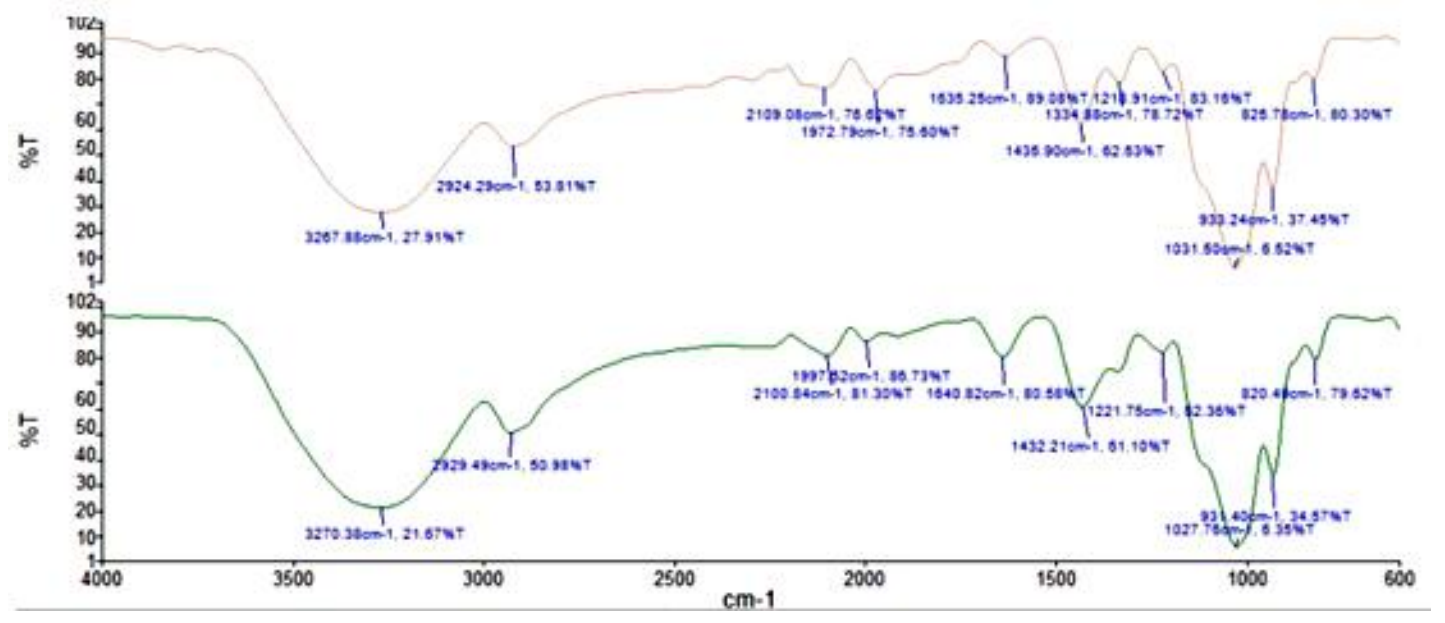

Gambar 1. Spektrum FTIR inulin umbi dahlia (bawah) dan inulin chicory (atas)

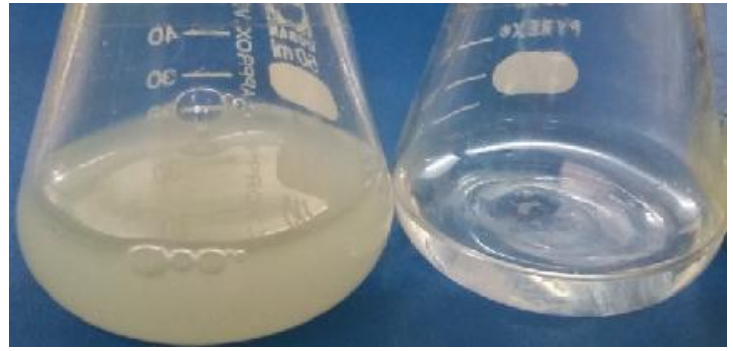

a

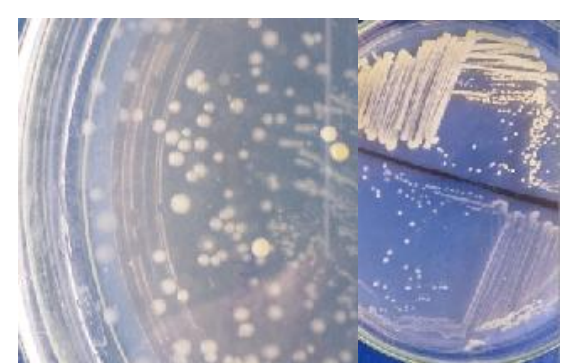

b

$\mathrm{c}$

Gambar 2. Bakteri pendegradasi inulin dari rizosfer umbi dahlia di Padang Panjang a.Bakteri pendegradasi inulin dari rizosfer umbi dahlia pada media cair (kiri keruh, kanan kontrol negatif) b.Bakteri pendegradasi inulin pada media padat c.Dua isolat bakteri pendegradasi inulin dari rizosfer umbi dahlia (RZ-01, RZ-02)

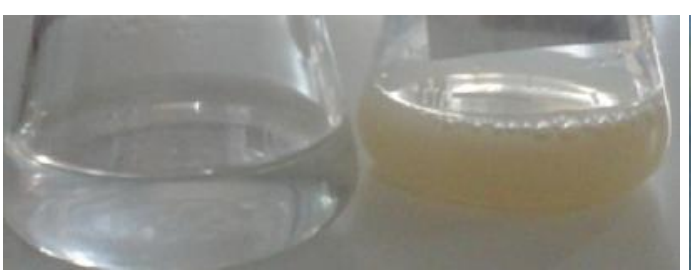

a

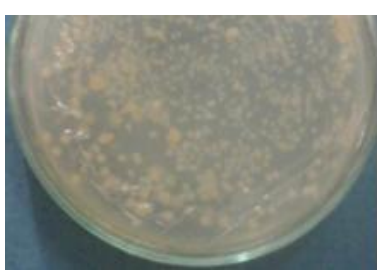

b

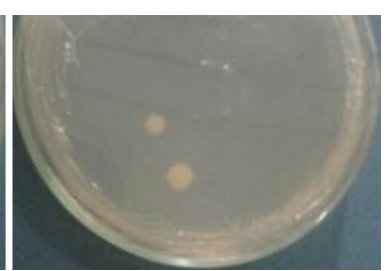

C

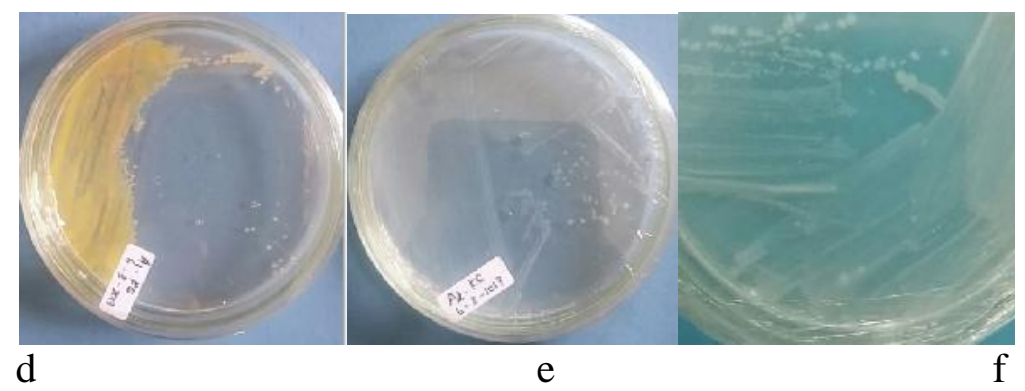

Gambar 3. Bakteri pendegradasi inulin dari rizosfer umbi dahlia di Solok a. Bakteri pendegradasi inulin dari rizosfer umbi dahlia pada media cair (kanan keruh, kiri kontrol negatif) b. dan c. Bakteri pada media padat d. e. dan $\mathrm{f}$. Tiga isolat bakteri pendegradasi inulin dari rizosfer umbi dahlia A1-KG, A2-KG dan UKG 


\section{Identifikasi koloni bakteri}

Bakteri pendegradasi inulin yang diperoleh dari rizosfer umbi dahlia berjumlah 5 isolat yaitu 2 isolat dari rizosfer umbi dahlia Padang Panjang dengan kode isolat RZ-01, RZ-02 dan 3 isolat dari rizosfer umbi dahlia di Solok dengan kode isolat A1-KG, A2-KG dan UKG. Ke lima isolat tumbuh baik pada suhu ruang dan suhu 40. Dengan demikian, isolat RZ-01, RZ-02, A1-KG, A2-KG dan UKG dapat dikelompokkan sebagai bakteri mesofilik. Bakteri mesofilik dapat tumbuh dengan baik antara suhu $10^{\circ} \mathrm{C}-45^{\circ} \mathrm{C}$, sedangkan bakteri termofilik dapat tumbuh dengan baik antara suhu $40^{\circ} \mathrm{C}-70^{\circ} \mathrm{C}$ (Madigan et al., 2012).

Bentuk koloni pada umumnya sirkular dan berwarna putih dan agak kekuningan (Tabel 2). Dengan demikian isolat bakteri BB3 merupakan isolat yang paling potensial untuk menghasilkan enzim pendegradai inulin termostabil. Enzim ini paling tepat digunakan untuk reaksi hidrolisis inulin menghasilkan fruktosa dan prebiotik FOS.

Tabel 2. Bentuk koloni isolat bakteri pendegradasi inulin dan uji termotoleran

\begin{tabular}{|c|c|c|c|c|}
\hline No & Isolat & Bentuk koloni & Uji & $\begin{array}{l}\text { Termo- } \\
\text { toleran }\end{array}$ \\
\hline & & & $\begin{array}{c}\text { Suhu } \\
\text { ruang }\end{array}$ & $40^{\circ} \mathrm{C}$ \\
\hline 1 & RZ-01 & $\begin{array}{l}\text { Koloni berbentuk sirkular, dengan tepi } \\
\text { koloni halus (entire), elevasi koloni naik, } \\
\text { sifat optikal koloni jernih, koloni agak putih }\end{array}$ & + & + \\
\hline 2 & RZ-02 & $\begin{array}{l}\text { Koloni berbentuk sirkular, dengan tepi } \\
\text { koloni berombak (undulate), elevasi koloni } \\
\text { naik (raised), sifat optikal koloni tidak } \\
\text { tembus cahaya (opaque), koloni agak } \\
\text { kekuningan }\end{array}$ & + & + \\
\hline 3 & A1-KG & $\begin{array}{l}\text { Koloni berbentuk sirkular, dengan tepi } \\
\text { koloni berombak (undulate), elevasi koloni } \\
\text { cembung (convex), sifat optikal koloni tidak } \\
\text { tembus cahaya (opaque), koloni agak } \\
\text { kekuningan }\end{array}$ & + & + \\
\hline 4 & A2-KG & $\begin{array}{l}\text { Koloni berbentuk sirkular, dengan tepi } \\
\text { koloni berombak (undulate), elevasi koloni } \\
\text { naik (raised), sifat optikal koloni tidak } \\
\text { tembus cahaya (opaque), koloni putih kecil }\end{array}$ & + & + \\
\hline 5 & UKG & $\begin{array}{l}\text { Koloni berbentuk sirkular, dengan tepi } \\
\text { koloni berombak (undulate), elevasi koloni } \\
\text { naik (raised), sifat optikal koloni tidak } \\
\text { tembus cahaya (opaque), koloni putih kecil }\end{array}$ & + & + \\
\hline
\end{tabular}

Keterangan : + artinya tumbuh 


\section{KESIMPULAN}

Berdasarkan hasil penelitian yang diperoleh dapat disimpulkan:

a. Bakteri pendegradasi inulin dari rizosfer umbi dahlia yang diperoleh berjumlah 5 isolat yaitu 2 isolat dari rizosfer umbi dahlia Padang Panjang dengan kode isolat RZ-01, RZ-02 dan 3 isolat dari rizosfer umbi dahlia di Solok dengan kode isolat A1-KG, A2KG dan UKG.

b. Bentuk koloni pada umumnya sirkular dan berwarna putih dan agak kekuningan

\section{Ucapan Terimakasih}

Penelitian ini didanai oleh DIPA UNP pada skim penelitian kerjasama antar Perguruan Tinggi dalam negeri an. Minda Azhar dengan nomor kontrak: 1795/UN35.2/PG/2017.

\section{DAFTAR PUSTAKA}

Allais, J.J; Hoyos-Lopez, G; Kammoun,S; Baratti, J.C. (1987). Isolation and Characteriztion of the Thermophilic Bacterial Strain with Inulinase Activity. Applied and Enviromental Microbiology. Vol.53(5): 942-945.

Andyani, N.F (2001). Produksi Sirup Fruktosa dari Inulin Dahlia Pinata Cav secara Hidrolisis Asam. Skripsi. Fakultas Teknologi Pangan IPB. Bogor.

Azhar, M; Syukur, S; Natalia, D; Vovien; Jamsari; Munaf, E. (2013) Characterization of extracellular enzyme and identification of inulin degrading bacteria from hot spring West Sumatra. International Journal of Chemistry. Vol.2 (1):3341.

Azhar, M; Oktavia B; Andrani N; Risa B; Natalia, D. (2015). Eksplorasi bakteri potensial pendegradasi inulin dari sumber air panas di Solok, Sumatera Barat. Jurnal Eksakta. Vol.1: 22-28.

Castro, G.R; Baigorf, M.D, Siheriz, F. (1995). A plate Technique for Screening of Inulin Degrading Microorganism. Journal of Microbiological Methods 22: 5156.

Ibrahim, A.S.S and El-diwany A (2007). Isolation and Identification of New Cellulases Producing Thermophilic Bacteria an Egyptian Hot Spring and Some properties of the Crude Enzyme. Australian Jurnal of Basic and Applied Sciences (4):473-478.

Kwon, H.J; Jeon, S.J; You, D.J; Kim, K.H; Jeong, Y.K; Kim, Y.H; Kim, Y.M; Kim, B.W. (2003). Cloning and characterization of exoinulinase from Bacillus polymyxa. Biotechnology Letter, 25:155-159.

Kulminskaya, A.A; Arand, M; Eneyskaya, E.V; Ivanen, D.R; Shabalin, K.A; Shishlyannikov, S.M; Saveliev, A.N; Korneeva, O.S; Neustroev, K.N. (2003). Biochemical Characterization of Aspergillus awamori Exoinulinase: Substrate Binding Characteristics and Regio Selectivity of Hydrolysis. Biochimica et Biophysica Acta 1650:22-29.

Lu WD, Li AX, Guo QL (2014). Production of novel alkalitolerant and thermostable inulinase from marine actinomycete Nocardiopsis sp DN-K15 and inulin hydrolysis by the enzyme. Annals of Microbiology. 64: 441-449

Madigan, M.T; Martinko, J.M; Stahl, D.A, Clark, D.P. (2012). Brock Biology of Microorganisms, $13^{\text {th }}$ 
ed. San Francisco: Benjamin Cumming

Menendez, C; Hernandez, L; Selman, G; Mendoza, M.F; Hevia, P; Sotolongo, M; Arrieta, J.G. (2002) Molecular cloning and expression in Escherichia coli of an exo-lavanase gene from the endophytic bacterium Gluconaceto-bacter diazotrophicus SRT4. Current Microbiology, 45:5-12

Pontes AGO, Silva KL, Fonseca SGC, Soares AA, feitosa JPA, Braz-Filho R, Romero, NR, Bandeira MAM (2016). Identification and determination of the inulin content in roots of the Norteast Brazilian species Pombalia calceolaria L, Review. Carbohydrate Polymer 149:391-398.

Sambrook, J; Russell, D.W. (2001). Molecular Cloning a Laboratory Manual. $3^{\text {rd }}$ edition. New York: Cold Spring Harbor Laboratory Press

Sing RM; Chauhan K (2016). Production, purification, characterization and application of inulin-degrading Paenibacillus sp. LX16 newly isolated from Jerusalem artichoke root. Microb Biotechnol. 9(3):419-29

Zittan, L. (1981). Enzymatic Hydrolysis of Inulin an Alternative Way to Fructose Production. Starch, 33:373-377. fungal inulinase. Current Biotechnology 5:1-20

Singh,P; Gill, P.K. (2006). Production of Inulinase: Recent Advances. Food Technol Biotechnol 44(2):151-162.

Sirisansaneeyakul, $\quad$ S;

Worawuthiyanan, $\quad \mathrm{N}$;

Vanichsriratana, $\quad \mathrm{W}$;

Srinophakum, P; Chisti, Y (2007). Production of Fructose from Inulin Mixed Inulinases from Aspergllus niger and Candida guilliermondii. Word J Microbial Biotechnol 23:543-552.

Wanker, E; Huber, A; Schwab, H. (1995). Purification and characterization of Bacillus subtilis levanase produced in Escherichia coli. Applied and Environmental Microbiology, 61:1953-1958.

Yao Z, Guo J, Tang W, Sun Z, Hou Y, $\mathrm{Li}$ X.(2016). Production of a single cyclic type of fructooligosaccharide structure by 